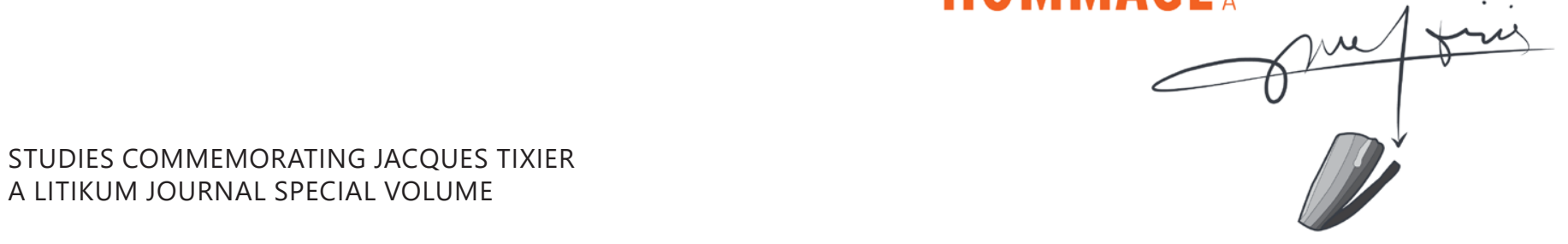

\title{
The knapped stone assemblage from Boldogkőváralja in the light of a new statistical evaluation
}

\author{
Norbert Faragó ${ }^{1}$, Zsolt Mester ${ }^{2}$, Attila Király ${ }^{3}$ \\ ${ }^{1}$ Corresponding author. Institute of Archaeological Sciences, Eötvös Loránd University, Budapest Email: farago.norbert@btk.elte.hu \\ ${ }^{2}$ Institute of Archaeological Sciences, Eötvös Loránd University, Budapest. Email: mester.zsolt@btk.elte.hu \\ ${ }^{3}$ Institute of Archaeological Sciences, Eötvös Loránd University, Budapest. Email: attila.kiraly@koveto.com
}

\section{Abstract}

Kivonat

Keywords

Kulcsszavak

Cite as • hivatkozás

Article history •

Kézirat történet

Copyright • Jogok
One of the most famous knapped stone assemblages, the 566 intact blades found in a large vessel at BoldogkőváraljaTekeres-patak, dated to the Bükk culture (5200-5000 BC) has been at the forefront of the research for decades. Our intention was three-fold when we decided to reevaluate this find. First, with the publication of the conjoining workshop material, we wanted to draw more attention to the whole assemblage and not just only to the depot. Second, the deliberate selection of the artefacts found in the jar has been suggested since the 1960s, which, in our opinion, can be tested by deep statistical analysis. Third, when Vértes applied parametric and non-parametric statistical analyses on knapped stone assemblages, he ventured into a brand new branch of archaeological investigation, not just in Hungary. Unfortunately, the pioneering attempts of Vértes were not followed for many decades. Our results suggest that the intact blades of the depot differed from each other significantly by their butt preparation because the pieces with dihedral butts are significantly wider than the others. On contrary, the length and the thickness of unbroken blades are homogenous, irrespective of preparation techniques. Concerning the different butt types across the whole assemblage, blades with plain butts are the most numerous in the depot and the workshops, but other, more thorough preparation occurred at a decreased rate in the workshops. At the same time, the different preparation types are evenly distributed in the four workshops, there are no significant differences between them.

\section{A boldogkőváraljai pattintott kő leletegyüttes új statisztikai értékelése}

A Bükk kultúrához (i.e. 5200-5000) tartozó Boldogkőváralja-Tekeres-patak lelőhelyen talált, 566 ép kőpengét rejtő edény lerakat hazánk egyik legismertebb pattintott kő leletegyüttese, mellyel sok korábbi kutatás foglalkozott már. Újraértékelésünk elsố célja, hogy a depóhoz csatlakozó múhelyek leletanyagára is felhívjuk a figyelmet. Második célunk volt, hogy az edényben talált tárgyak szándékos szelekciójának elméletét statisztikai módszerekkel vizsgáljuk. Ezzel összefüggésben harmadik célunk volt, hogy a kőpengéket korában egyedülálló módon statisztikai módszerekkel vizsgáló Vértes László munkásságát folytassuk hazánkban. Eredményeink szerint a depó ép pengéi között a kétlapú talonnal rendelkezők szignifikánsan szélesebbek voltak a többinél. Ezzel ellentétben az ép darabok hosszúsága és vastagsága hasonló, függetlenül a preparációs technikáktól. A depó és a műhelyek anyagában egyaránt a sima talonú darabok a leggyakoribbak, de az alaposabb előkészítés inkább a depóba helyezett pengéken figyelhető meg. Ezen felül a különféle preparációs típusok megoszlása egyenletes a négy múhely anyagában, vagyis ezek a leletcsoportok egymásra hasonlítanak.

Neolithic, Bükk culture, lithics, statistics, structured deposition

neolitikum, Bükk kultúra, pattintott kövek, statisztika, strukturált depozitum

Faragó, N., Mester, Zs., \& Király, A. (2019-2020). The knapped stone assemblage from Boldogkóváralja in the light of a new statistical evaluation. Litikum, 7-8 (Studies commemorating Jacques Tixier), 55-70. https://doi. org/10.23898/litikuma0025

Received | Érkezés: 2021. 07. 01. Accepted | Elfogadás: 2021. 07. 05. Published | Közzététel: 2021. 08. 04.

This is an open-access article distributed under the terms of the Creative Commons Attribution License, which permits unrestricted use, distribution, and reproduction in any medium, provided the original author and source are credited. | Ez egy nyílt hozzáférésű publikáció, amit a Creative Commons 4.0 licensze véd. A termék szabadon használható, terjeszthető és sokszorosítható az eredeti szerző és forrás megjelölése mellett. 


\section{Introduction}

Considering knapped stone tools, the larger part of the Middle Neolithic (5400-5000 BC), thus the later episodes of the Alföld Linear Pottery culture are underrepresented in the literature. Moreover, the known sites and assemblages are modest, sometimes containing only a handful of pieces (Biró 1987; Biró 1998; Kaczanowska 1985). However, the relatively high ratio of obsidian (more than $50 \%$ on average) testifies the continued importance of this raw material from the former periods in the Hungarian Plain. The last decade witnessed some modest results concerning new data from new sites, such as Polgár-Ferenci-hát (Site 31) (Kaczanowska et al. 2016; Kaczanowska \& Kozłowski 2016), Polgár-Piócási-dűlő (Nagy et al. 2014; Kaczanowska \& Kozłowski 2016) and TiszaugVasútállomás (Füzesi et al. 2017). At the first mentioned site, dated to the latest phase of the Alföld Linear Pottery (ALP) culture, at least two obsidian core reduction strategy was recorded, one with flat debitage surface, and one with cylindrical debitage surface. In some cases, the pressure technique was hypothesized according to the analysis of the obsidian blades. The most numerous tools are end-scrapers, laterally retouched blades, and truncations. Polgár-Piócási dúlő yielded settlement features both from the early and the latest phase of this cultural unit, with almost exclusive utilization of obsidians. One interesting difference between the two chronological horizons is the length of the blades, as the earlier specimens are larger. At Tiszaug, in the southern part of the Hungarian Plain, only a handful of stone tools were collected, but one-quarter of the pieces were made on obsidian (Füzesi et al. 2017). This settlement, dated to the Szakálhát culture, displays important connections with Transdanubia in the form of radiolarite artefacts, and these connections became more intensive in the Late Neolithic period.

One of the most famous assemblages, BoldogkőváraljaTekeres-patak, which is situated in the North Hungarian Range and belongs to the Bükk culture (5200-5000 BC) has been at the forefront of the research for decades (Fig. 1) (Biró 1998; Kaczanowska 1985; Mester \& Tixier 2013; Vértes 1965). However, this assemblage is peculiar in many respects. First, the abundance of obsidian raw material characteristic of contemporaneous sites is not present here at all, as this raw material counts only $3 \%$ of the whole assemblage. Second, the 566 intact blades of a local raw material (limnosilicite) (Mester \& Faragó 2016) and found in a large vessel at Boldogkőváralja, are particular in themselves. This find context has been the subject of several preceding studies. Among these, Vértes' statistical study was highly uncommon in the archaeological literature before (Vértes 1965). He argued that the metrical results following normal distribution around a specific size suggest standardized manufacturing for a special purpose, thus it can be a cultural marker for a specific industry. Later, the blade depot was discussed from a technological point of view in detail, with the conclusion that the similarity of these pieces is rather the result of specialist knapping activity. (Mester \& Tixier 2013). According to the latter authors, these blades have been stored in a vessel accessible to the whole community. In another article, the intertwined relationship between ritual and domestic activities was emphasized through the case study of the blade depot of

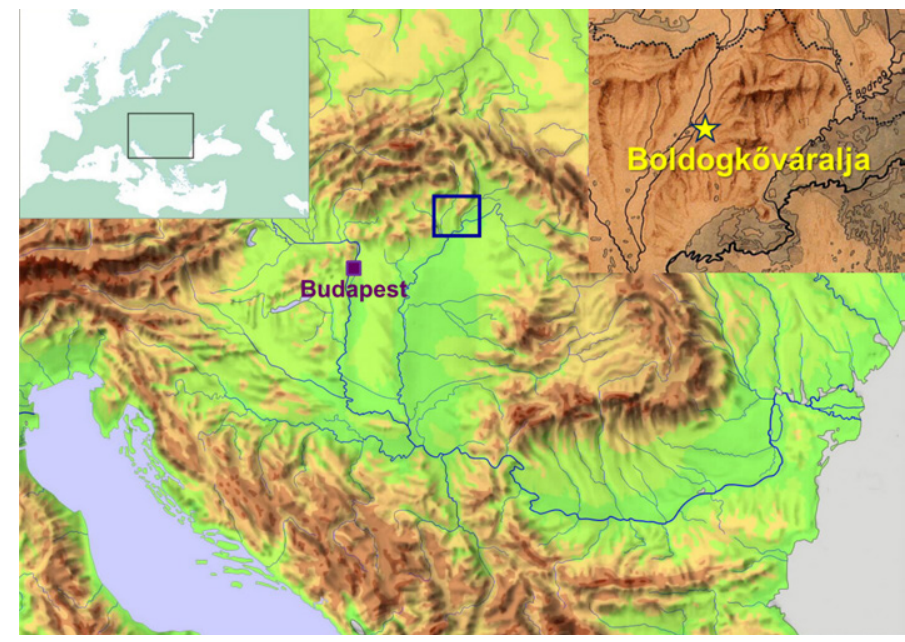

Figure 1. Location of the Boldogkőbáralja site in Hungary. Map: Zsolt Mester.

Boldogkőváralja. (Király et al. 2020). In this approach, the authors interpreted the knapping activity, the selection of the blades, and their deposition in the pot as possible elements of a complex ritual, which is difficult to distinguish from everyday practices. However, a detailed evaluation and publication of the lithic material from the workshops in the vicinity of the depot, never have been conducted. The only person, who investigated the material from the settlement features, only briefly mentioned the apparent metrical differences between the items from the depot and the other settlement features (Kaczanowska 1985, 52-53).

Our intention was three-fold when we decided to reconsider the analysis of the material of Boldogkóváralja-Tekerespatak. First, with the thorough evaluation and publication of the conjoining workshop material, we wanted to draw attention to the entire assemblage from the site, not just the depot. Second, the deliberate selection of the pieces in the jar has been suggested since the 1960s (Király et al. 2020; Mester \& Tixier 2013; Vértes 1964). At the same time, the intention of this act is obscure, and may not be ever clear, but in our opinion, it can be approached with the help of deep statistical analysis. Third, Vértes' parametric and non-parametric statistical analyses on knapped stone assemblages represent a brand new branch of archaeological investigation, not just in Hungary. At that time, natural scientific methods had just found their way into the research with the advent of new archaeology (Clarke 1968). Unfortunately, the pioneering attempts of Vértes had not been followed for many decades and statistics found their way into Hungarian Paleolithic archaeology only in the past few years (Lengyel 2018). Meanwhile, not just univariate or bivariate, but several multivariate statistical examples were introduced in the international literature already in the early years (Binford \& Binford 1966; Dolukhanov et al. 1980; Hodson 1969). Seemingly, scholars interested in the Palaeolithic period and stone tools always have been more aware of such methods and investigations (Király 2018; Scerri et al. 2016). 


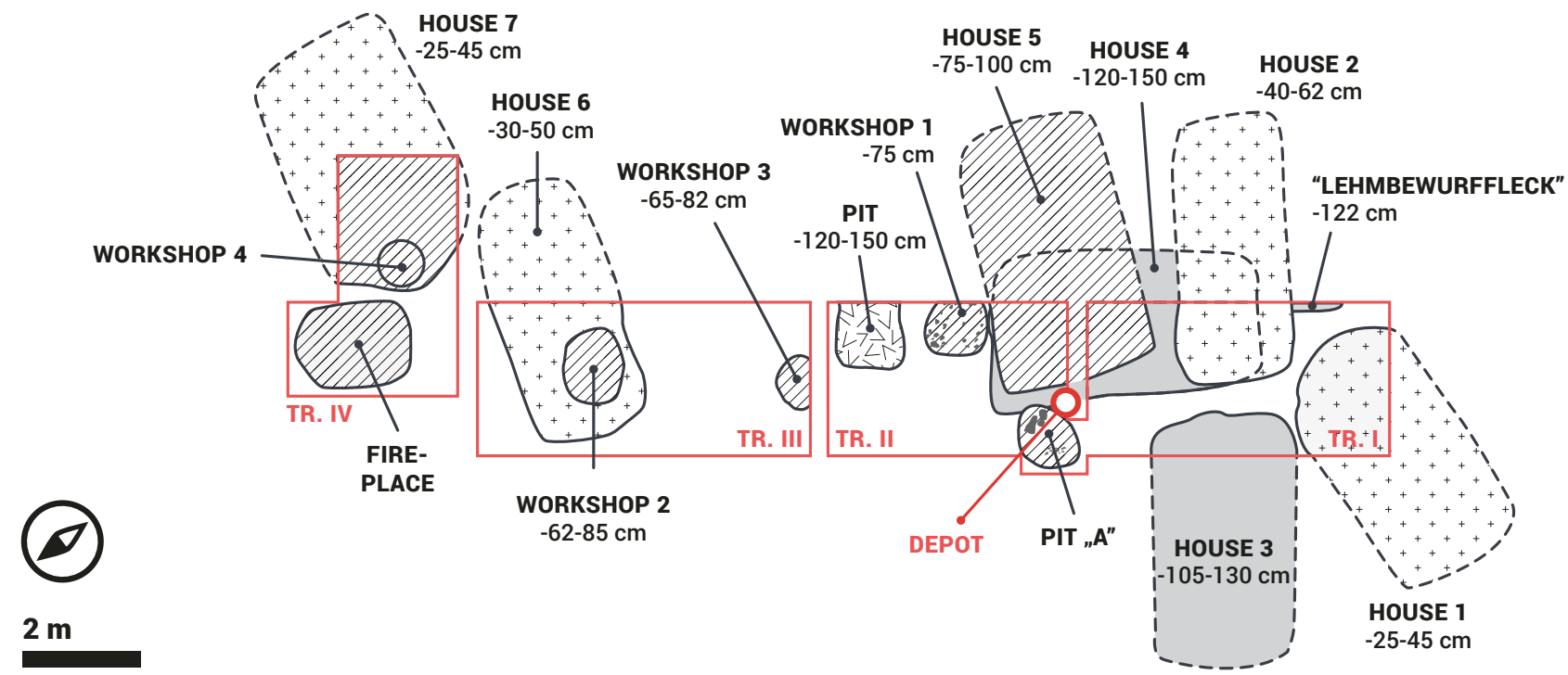

\section{BOLDOGKÖVÁRALJA-TEKERES-PATAK}

After Kalicz \& Makkay 1977, Abb. 10, p. 68; Abb 11, p.69.

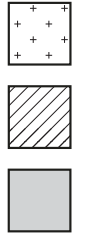

Upper level (30-50 cm depth)

Depot (middle level)

Middle level (60-80 cm depth)

Trenches

Lower level (110-130 cm depth)

--- Unexcavated

Figure 2. Excavation plan with the houses, workshops and other features belonging to the early (grey), middle (diagonal lines) and late (crosses) settlement phases, and the excavation trenches (red line). Assembled by Attila Király after Kalicz \& Makkay 1977, Abb. 10 and 11.

\section{Materials and methods}

\subsection{The archaeological site}

Boldogkőváralja-Tekeres patak was discovered during road construction works by Tibor Kemenczei in 1963 (Kemenczei 1964). The site had been located near the Tekeres stream, where five trenches of 8-12.5 square meters were excavated (Fig. 2). During the excavation, 7 houses, 4 workshops, a pit, and a hearth were unearthed in four trenches. The settlement remains were dated exclusively to the Bükk culture according to the diagnostic ceramic material (Kalicz \& Makkay 1977, 68-71). Based on the field observations, Kemenczei argued for two distinct settlement phases, situated between 20 and $160 \mathrm{~cm}$ below the topsoil. This idea was not confirmed by the ceramic analysis conducted later by Kalicz and Makkay $(1977,70)$, because all the sherds seemed to fit into the first phase of the Bükk culture. The famous depot in the standing vessel was found in Trench II, between House 5 and Pit 'A'.

Revising the observed depth of the different settlement features, we argue for three distinct settlement phases. The earliest part of the settlement was observed only in the southern zone in Trench I and II, represented by Houses 3 and 4 at 110$130 \mathrm{~cm}$ below the surface. The next level was situated in the central zone of the excavation between $60-80 \mathrm{~cm}$. below the surface. Most of the activities, such as the erection of House 5, the establishment of the four workshops and Pit 'A', and the deposition of the vessel are dated to this period. Even Kemenczei associated these features with each other, representing one single settlement period. Finally, Houses 2, 6, and 7 at the level of $30-50 \mathrm{~cm}$ below the surface, in the distal part of the excavation area (Trench I, III, and IV) represent the last phase of occupation.

According to the examination of Piroska Csengeri, the jar containing the blades had been originally manufactured to store liquids, and after certain repairs, it ended up serving other purposes. Moreover, according to the remains cemented on the bottom and lower part of the outer wall, the lower half of the vessel was sunken into the soil while the upper half remained accessible above-ground.

\subsection{Knapped stones}

The excavation conducted at Boldogkóváralja yielded altogether 1083 knapped stone implements. Among them, the blade depot counted 566 pieces of intact and broken blades. Apart from that, four concentrations or workshops of knapped stones came to light with another 331 pieces of cores, flakes, and blades. 66 pieces were attributed to a feature named Pit 'A', but half of it were made of obsidian, so these pieces and further stray finds have been excluded from the present study. 


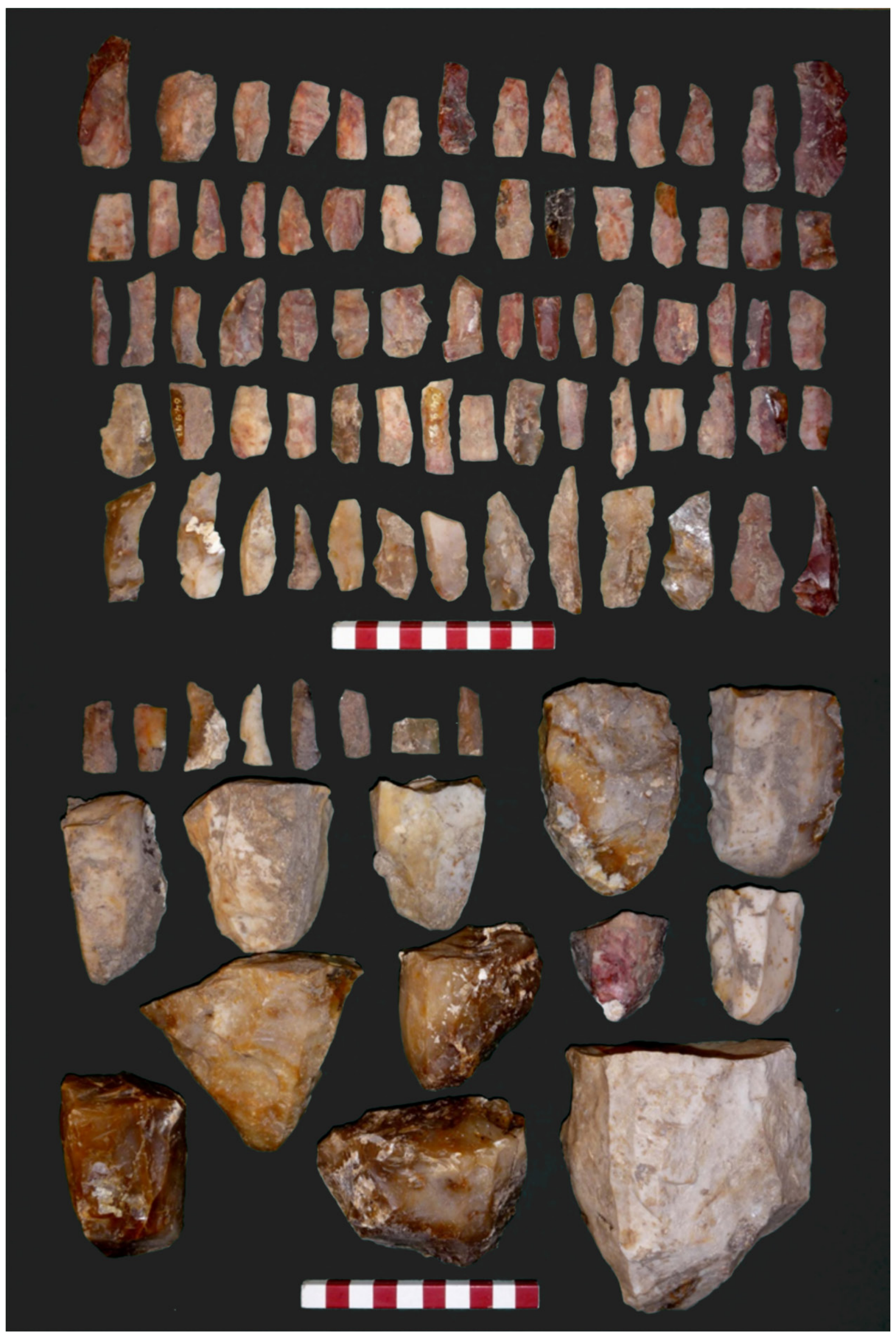

Figure 3. Boldogkőváralja-Tekeres-patak, knapped stone implements and cores from Workshop 1. Photo: Norbert Faragó, courtesy of the Herman Ottó Museum in Miskolc. 


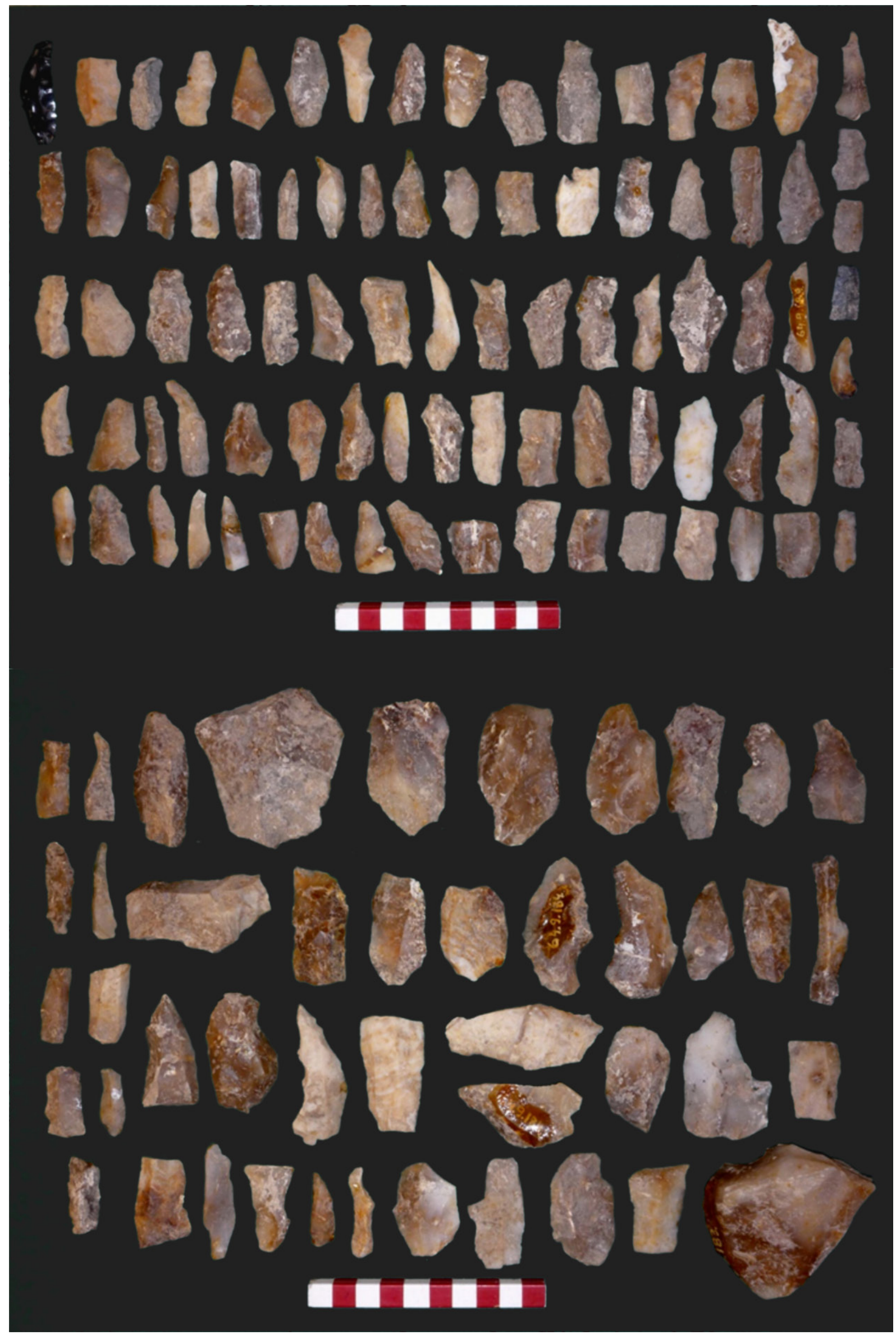

Figure 4. Boldogkőváralja-Tekeres-patak, knapped stone implements and cores from Workshop 2. Photo: Norbert Faragó, courtesy of the Herman Ottó Museum in Miskolc. 


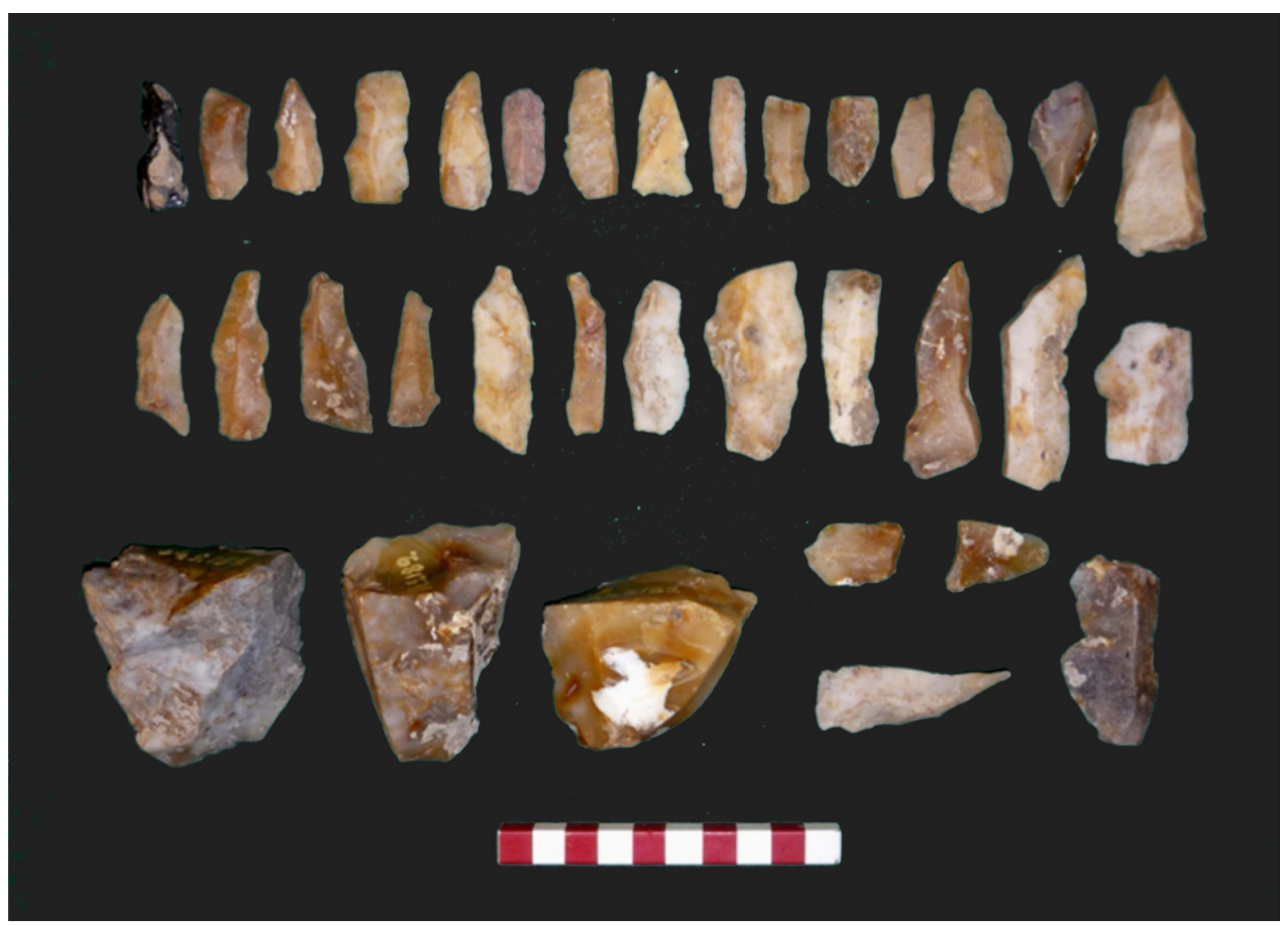

Figure 5. Boldogkőváralja-Tekeres-patak, knapped stone implements and cores from Workshop 3. Photo: Norbert Faragó, courtesy of the Herman Ottó Museum in Miskolc.

The distribution of finds among the workshops is uneven; the most abundant is Workshop 2 with 111 knapped stones (Fig. 3-6). Among these, 93 pieces are blades or blade fragments, while the rest were cores, flakes, and debris. Workshops 1 and 4 contained 93 pieces each, from which 81 and 75 blades and blade fragments were chosen for the analysis respectively. Finally, Workshop 3 contained the least amount, 25 pieces suitable for study.

According to the database of Jacques Tixier and Zsolt Mester about the depot, we observed the following attributes on the pieces from the workshops: length, width, width at the mesial section, thickness, curvature, and butt type. To ensure compatibility and integrity with the depot dataset, we decided to include our measurements in the original database of the mentioned authors.

In our study, both parametric (ANOVA, Levene's, Welch) and non-parametric (Chi², Kruskal-Wallis, Mann-Whitney pairwise) tests were conducted with the application of the PaST 3.22 statistical software (Hammer et al. 2001). Every analysis was introduced by normality tests, which determined the method of comparison to follow. In the case of non-normal distribution, which was more frequent, Levene's test from median has been applied. If unequal variance occurred between the data series, the Welch test completed the evaluation. In parallel with the comparisons of the means, especially when non-normal distributions or unequal variances occurred, the medians were also compared with the help of Kruskal-Wallis and Mann-Whitney paired tests.

\section{Results}

\subsection{Metric analysis}

First, the metric attributes of the blades in the depot were investigated in more detail. The width of the intact blades was compared by the preparation technique of the blades (Fig. 7). According to the normality tests, the distribution of the butt types among blades is normal except for plain butts. In this case, the ANOVA test was run with the aid of Levene's test for homogeneity of variance from the median $(p=.910)$. The result was a significant difference between the means of the blade widths $(F[4,392])=3.10 ; p=.016)$. To check the medians of the same data, the Kruskal-Wallis test was applied with similar results: they differed significantly $(H=12.51$; $p=.014)$. According to the Mann-Whitney pairwise test, the greatest distance occurred between the blades with dihedral and facetted, and dihedral and plain butts.

Blades lengths have been analysed in the same manner. First, normality tests were conducted, with similar results (Fig. 8). This time, blades with dihedral butts displayed nonnormal distribution. Second, ANOVA and Levene's test have been run with the same results, both the variances $(p=.805)$ and means were found to be the same $(F[4,392]=1.70 ; p=.178)$. For the medians, the Kruskal-Wallis test showed strong similarity $(H=6.63 ; p=.157)$.

The analysis of blade thickness yielded similar results (Fig. 9). Except for atypical and crushed butts, all types followed 


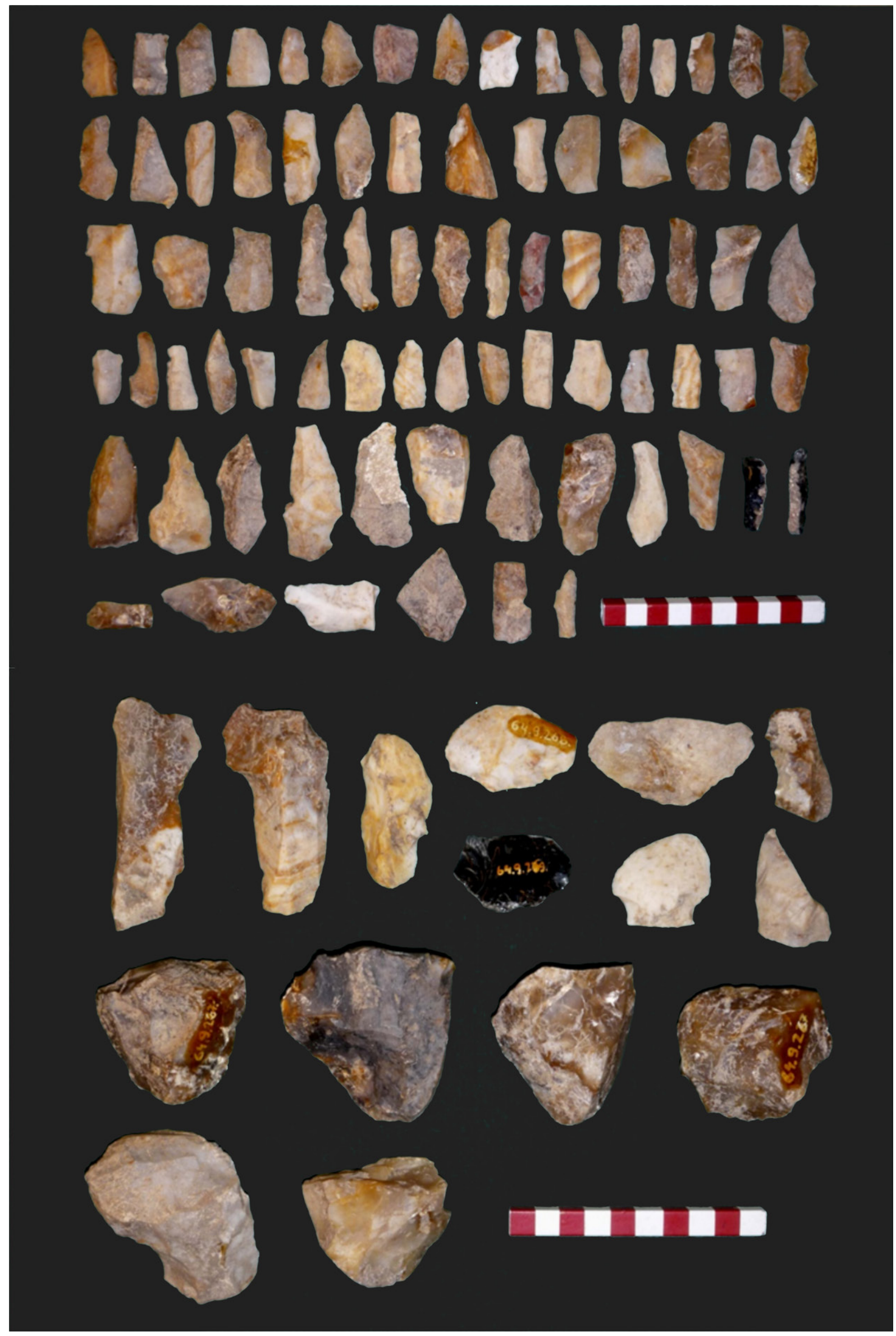

Figure 6. Boldogkőváralja-Tekeres-patak, knapped stone implements and cores from Workshop 4. Photo: Norbert Faragó, courtesy of the Herman Ottó Museum in Miskolc. 
non-normal distribution. Levene's test from medians showed that the variances are the same $(p=.551)$, so as the means $(F[4,392]=1.80 ; p=.128)$ and the medians $(H=6.68$; $p=.136)$.

Next, the curvature of the intact blades with different butts has been compared with the same tests (Fig. 10). The normal distribution requirements of the ANOVA were strongly violated by the samples, only the blades with atypical butts followed a normal distribution. In this case, it was obvious that Levene's test from median has to be taken into consideration, which resulted in a very homogenous variance $(p=.9488)$. Nevertheless, both means $(F[4,392]=4.18 ; p=$ .003) and medians which were tested with the Kruskal-Wallis method $(H=16.28 ; p=.003)$ differed significantly. To identify the inherent relationships in the dataset, paired Mann-Whitney tests had been conducted again, which showed that the difference is the most significant between pieces with dihedral and facetted, and between pieces with dihedral and plain butts.

Lastly, the width of all pieces of the depot, broken or nonbroken were taken into consideration (Fig. 11). According to the normality tests, the distribution of pieces with dihedral and plain butts violated the normal distribution requirements. Again, Levene's test from median was applied to inspect the homogeneity of variances, which resulted in the same variance $(p=.891)$. The ANOVA showed that the means differ significantly $(F[4,514]=4.22 ; p=.002)$, while the Kruskal-Wallis test verified the same for the medians ( $H=16.25 ; p=.003)$. The underlying cause behind these heterogeneous distributions is the distribution of blades with dihedral butts again. According to the paired Mann-Whitney test, those blades are significantly wider than the blades having crushed, facetted, or plain butts.

The statistical evaluation of the entire assemblage was started with the investigation of blade butts (Table 1). The question arose whether the same distribution can be recorded in the depot and the workshops or not. Atypical, dihedral, crushed, facetted, and plain butts together offered an adequate sample to analyse. According to the $\mathrm{Chi}^{2}$ test, there is a significant difference between the different assemblages concerning the distribution of butt types $\left(X^{2}=85.50 ; d f=16 ; p<.001\right)$. Having a closer look at the distribution, only one common attribute can be noted: the most frequent butt type is plain among the whole assemblage. The facetted type is the second most abundant in the depot, while the workshops contained only a minor quantity of them. Instead, atypical butts, together with the dihedral type in equal quantities were the second most frequent groups in the workshop samples, while the depot contained only a few atypical pieces. We ran a distinct $\mathrm{Chi}^{2}$ test only on the workshops to see the degree of the difference between them. The result was striking: there is no significant difference between the butt type distribution of the four workshops. $\left(X^{2}=10.92 ; d f=12 ; p=.536\right)$.

Beyond the apparent differences in the metric attributes of the blades from the depotand the workshops (Kaczanowska 1985, 52-53), we elaborated their relationship in more detail. First, the most obvious difference, the length of the whole blades were compared with each other (Fig. 12). This time, it seemed useless to run any tests, because the boxplot convincingly showed that the blades of the depot are much longer. However, we confronted the workshop assemblages with each other by ANOVA and Kruskal-Wallis tests. According to the results, the means and the medians are all the same throughout the four workshops $(F[3,53]=0.53 ; p=.667 ; H=2.70$; $p=.439)$, moreover, their distribution was normal.

At the same time, the width data seemed less different, so it was not futile to run statistical tests on them (Fig.13). According to the normality tests, the width of the depot blades are not following normal distribution, but the blades of the workshops do. According to Levene's test from medians, the variances are not homogenous $(p<.001)$, so the Welch F-test was applied. The result was a definitive difference between the means $(F=6.77 ; d f=17.96 ; p<.001)$, reinforced by the Kruskal-Wallis test for medians $(H=24.12 ; p<.001)$. MannWhitney pairwise tests helped to clarify the inherent relationship between the five assemblages, which reported that Workshop 1 falls close to the depot, while Workshops 2 and 3 are the most different in this sense.

Analysing the blade thickness throughout all the assemblages, the depot seemed to be substantially different from the workshops again (Fig. 14). Blade thickness distributions are not normal, while the variances $(p<.001)$, the means $(F=4.12$; $d f=17.52 ; p=.001)$, and the medians $(H=24.65 ; p<.001)$ are all heterogeneous. The Mann-Whitney pairwise test revealed that Workshop 1 stands close to the depot, while the rest of the workshops are more similar to each other again.

Theoretically, the curvature of the whole blades are closely related to the length of the blades (Fig. 15). As the blades of the depot are much larger, so one would expect more curved pieces in this assemblage as well. According to the boxplot, this claim is true, as the values of the depot are much higher than the workshops. Comparing again the four workshops with each other, non-normal distributions were experienced this time. However, Levene's test of variance from medians reinforced the homogeneity of these assemblages, and their means and medians were proved to be the same again $(F[3,53]=0.37 ; p=.776$; Kruskal-Wallis $H=3.35 ; p=.310)$.

The last aspect investigated is the width of all broken and unbroken blades from the depot and the workshops (Fig. 16). The normality tests resulted in a non-normal distribution in all cases, so Levene's test from medians was applied to test the variance $(p<.001)$. The inhomogeneous variances allowed only the application of the Welch F-test, which showed that there is a significant difference between the medians of the different assemblages. $(F=12.15 ; d f[$ total $]=128.8 ; p<.001)$ The Kruskal-Wallis test reinforced this suggestion with the comparison of the medians ( $H=65.30 ; p<.001)$, while the MannWhitney pairwise test shed light on the distance between the depot and the rest of the workshops. 

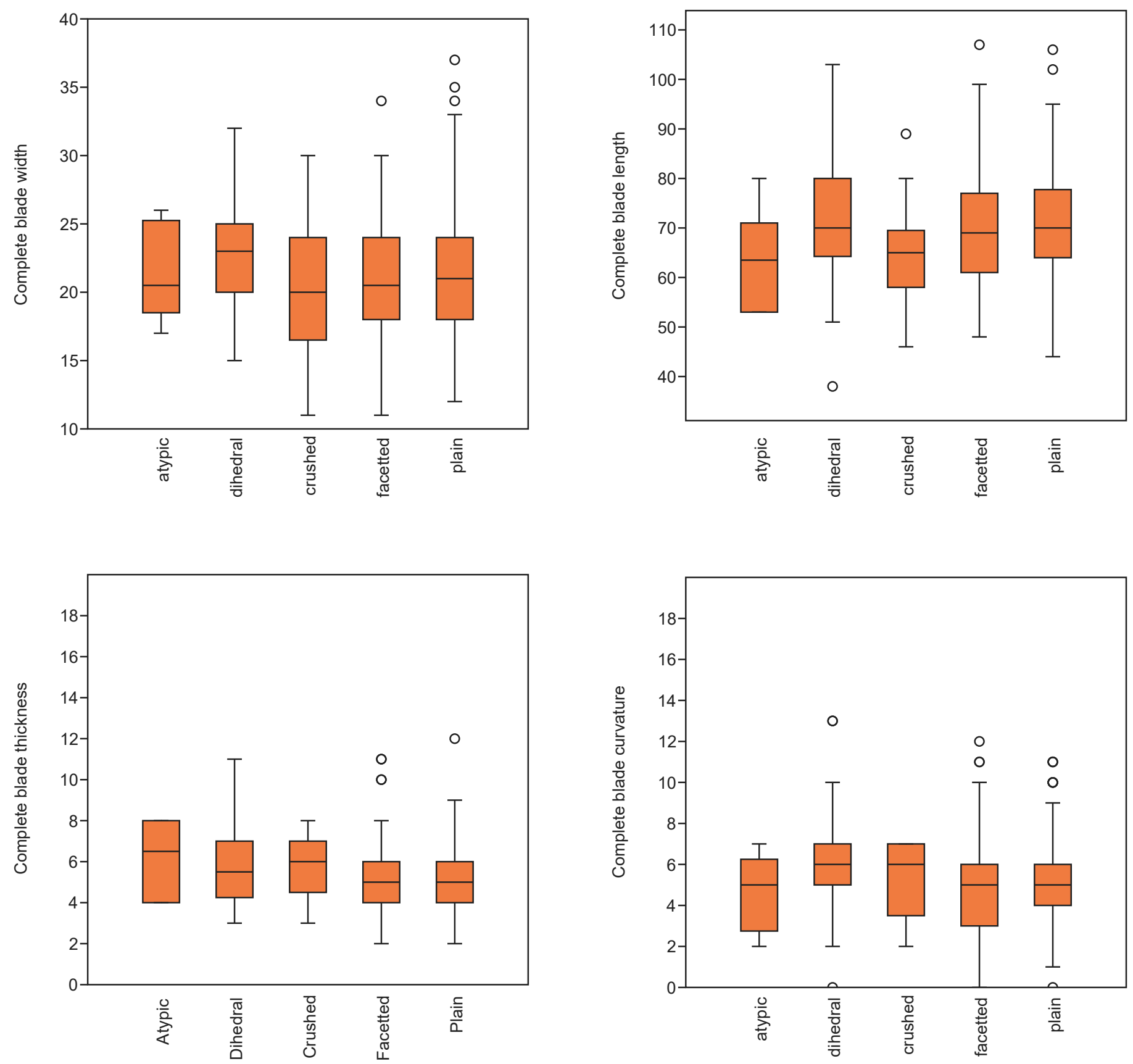

Figure 7-10. Boldogkőváralja-Tekeres-patak, metric attributes of the complete blades with different butts (atypic, dihedral, crushed, facetted, plain). Upper left (Figure 7) - width; upper right (Figure 8) - length; lower left (Figure 9) - thickness; lower right (Figure 10) curvature. Scale is in millimeters. Assembled by Norbert Faragó.

\section{Discussion}

Although the Neolithic is more representative concerning the number of sites and the knapped stone tools than the Paleolithic, stone tools in obviously special deposits like the Boldogkóváralja example are very scarce in the territory of Hungary even in the former period. Apart from knapped stones deposited in graves (Faragó 2017; 2019; Siklósi 2013), our knowledge about the complex role of these artefacts in the one-time social life is extremely limited. A similar deposit from Early Neolithic times, in the context of the Körös culture, has been found at the site Endrôd 39 (Kaczanowska et al. 1981). Here, a $50 \times 50 \mathrm{~m}$ area was excavated for about five seasons beginning in 1975, under the direction of János Makkay in connection with the fieldwork of the MRT (Magyar
Régészeti Topográfia - Hungarian Archaeological Topography). A total of three houses and six pits were excavated, and the finds in question were recovered in the north-western half of the excavation area in 1976. To the west, near a partially excavated building, a stone hearth was found. Adjacent to the latter, an ash pit came to light, containing a rounded, cylindrical-necked jar covered with a fragment of a base, with 101 knapped artefacts inside. The stones all showed a southern origin, with raw material from the western Banat or the pre-Balkan plateau. Their technological characteristics were also fairly uniform, being exclusively flakes associated with a later stage of core reduction. The refitting analysis of a few pieces also provided an excellent sketch of the tool production process, with the authors assuming three cores. 


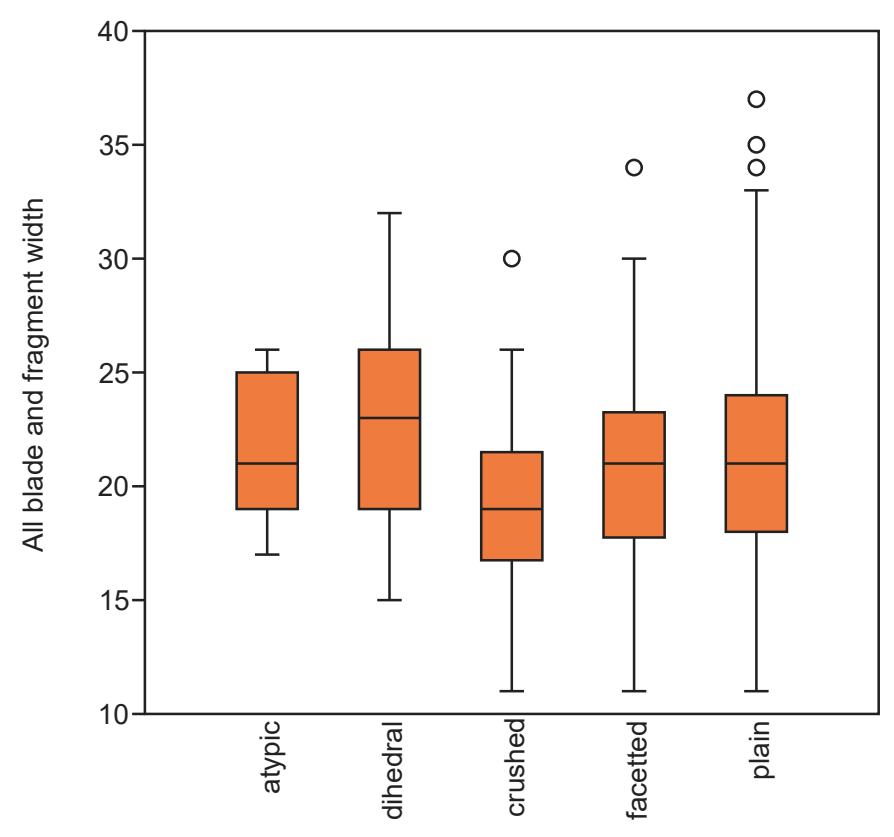

Figure 11. Boldogkőváralja-Tekeres-patak, width values of the complete and fragmentary blades with different butts (atypic, dihedral, crushed, facetted, plain). Scale is in millimeters. Assembled by Norbert Faragó.

Similar depositions are also known from the Late Neolithic period, the Hungarian example mentioned here is from Szegvár-Túzköves (Biró 2009). The site itself is a multi-layered tell settlement, typical of the Hungarian Plain region and the period, and it is well known in Hungarian and even international research (Tálas 1987). Excavations had been carried out here for several decades, but for us, it is the work conducted in 1955 that is of interest, when a small cup-shaped vessel containing 37 stone blades was found on a building's floor during the excavation led by József Csalog. Of these finds, 33 have survived until now, except one limnosilicite item, all are radiolariates of the Úrkút-Eplény and Szentgál types from the Transdanubian region. The refitting tests were successful, almost half of the finds were (14) matching pieces (Biró 2009). The remaining blades also appeared to fit in some way into the same production processes, with a total of three different starting cores assumed. Although the blades are not retouched, the analysis of their use-wear showed their utilization, and they fit well into the general picture of the material of the tell.

Even from these rare examples, it can be stated, that the guiding principles in the establishment of these contexts vary from site to site. The only fixed element connecting these cases is the presence of a vessel as a container for the selected stone tools. Other aspects driving the selection depended on the local community and its traditions, general attributes are difficult to identify. The numerous and diverse theoretical branches of archaeology have already come to the same conclusion that the exact context of a given find assemblage is as important during the interpretation as the artefacts itself (Gosden \& Malafouris 2015; McNiven 2013; Hodder 1991; Renfrew \& Zubrow 1994; Robb 1998,). The introduction of the neutral term "structured deposition" came in handy where any "ritual" or "symbolic" interpretation might

\begin{tabular}{lrrrrr} 
& Atypic & Dihedral & Crushed & Facetted & Plain \\
Depot & 6 & 80 & 13 & 138 & 160 \\
Workshop 1 & 6 & 6 & 1 & 4 & 26 \\
Workshop 2 & 4 & 7 & 1 & 4 & 31 \\
Workshop 3 & 3 & 1 & 0 & 0 & 13 \\
Workshop 4 & 2 & 7 & 4 & 2 & 31 \\
\hline
\end{tabular}

Table 1. Boldogkőváralja-Tekeres-patak, distribution of butt types in the depot and the four workshop areas. Assembled by Norbert Faragó.

emerge (Richards \& Thomas 1984). However, the excessive use of the term for almost every archaeological feature and phenomenon could result also in a misleading interpretation (Fogelin 2007; Garrow 2012).

During their analysis, Tixier and Mester emphasized the apparent differences between Endrőd, Boldogkőváralja and Szegvár, while they set foot in a strict material and functional domain during their interpretation (Mester \& Tixier 2013, 181-183). Later, the possibility of a one-time ritual practice has been formulated during the analysis of the Boldogkőváralja blade assemblage, highlighting only some selected arguments (Király et al. 2020).

\section{Conclusion}

To sum up, the intact blades of the Boldogkóváralja depot differed from each other significantly by their butt preparation, because there is a correlation between butt types and width. The pieces with dihedral butts are significantly wider than the others, especially with facetted or plain butts. On the contrary, the length and the thickness of unbroken blades are very homogenous, irrespective of their preparation techniques. However, not length but width is in concordance with the angle of inclination in this sense, as pieces with dihedral butts are more curved than the others. Again, the differences between dihedral and facetted, and dihedral and plain butts are the largest. Taking into consideration the width of all pieces in the depot (broken and unbroken) the same observation was made, as pieces with dihedral butts are significantly wider than others.

Investigating the distribution of the different butt types across the whole assemblage, it was verified again that the depot stands out compared to the four workshops. While blades with plain butt are the most numerous in the depot and the workshops also, other, more thorough preparations occurred less frequently in the workshops. It has to be stressed, that the presence of the different preparation types is evenly distributed in the four workshops, there are no significant differences between them. It is possible, that careful butt preparation was more useful to get more suitable detachments for the depot, but in an everyday context, more simple methods were preferred. On the other side, the formation of dihedral butts also would have been inappropriate, if width and angle of inclination had been as important as length. Pieces with dihedral butts are significantly wider and more curved than the others. 

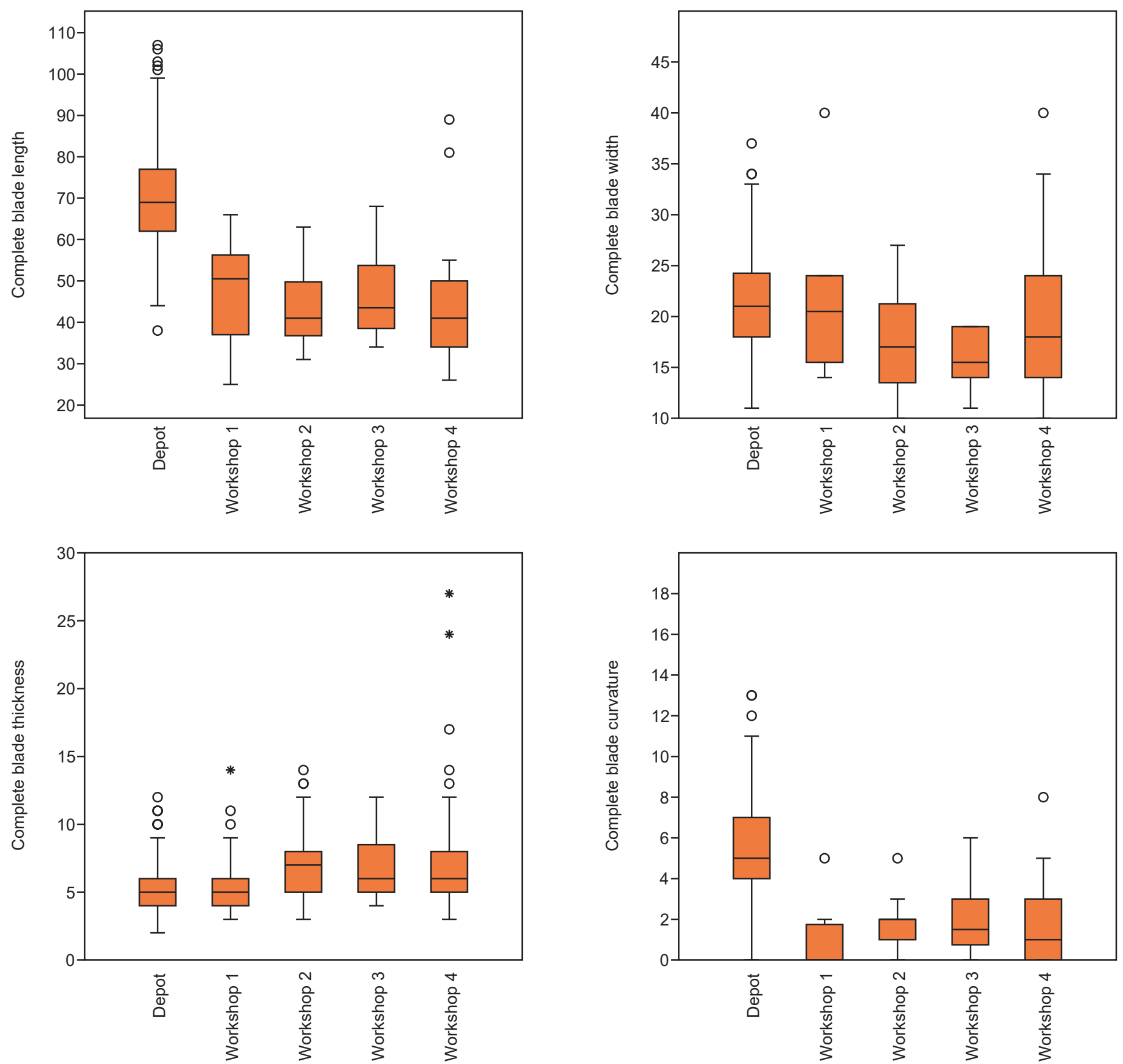

Figure 12-15. Boldogkőváralja-Tekeres-patak, metric attributes of the complete blades of the five assemblages (the depot and Workshops 1-4). Upper left (Figure 13) - width; upper right (Figure 14) - length; lower left (Figure 15) - thickness; lower right (Figure 16) - curvature. Scale is in millimeters. Assembled by Norbert Faragó.

The metric attributes of the workshops suggest the priority of the length and thickness above other measures when pieces were chosen for the depot. Whole blades left in the workshops are significantly smaller, thinner, and a bit narrower. Concerning the width of all blades and blade fragments in all assemblages from the site, this difference becomes more apparent, as the blades from the depot are much wider. The angle of inclination was in correspondence with these observations, as blades deposited in the jar are more curved than the others.

The concept of chaîne opératoire has been formulated in the 1960s thanks to the trailblazing work of André Lerhoi-Gourhan (Lerhoi-Gourhan 1964; 1965). Later on, several French scholars helped to transform it into a coherent theoretical framework about the complex relationship between technology and society (Pelegrin et al. 1988; Texier \& Meignen 2012; Tixier 2012). According to this framework, the production process possesses a structure with phases and sub-phases. At certain points of this process, it is possible to deviate from a given course of events, but there are points at which it is critical to do so (Lemonnier 1989). So, tool-making itself is not only a process determined by natural laws and raw material constraints, but also has a strong human component that is culturally determined (Schlanger 1994). Moreover, the mind which encounters raw material constraints and technological possibilities is necessarily pragmatic and creative, but there is also an intellectual, theoretical aspect of thinking which views the whole process and the cultural choices it contains, from the inside out as a complex and reversible 


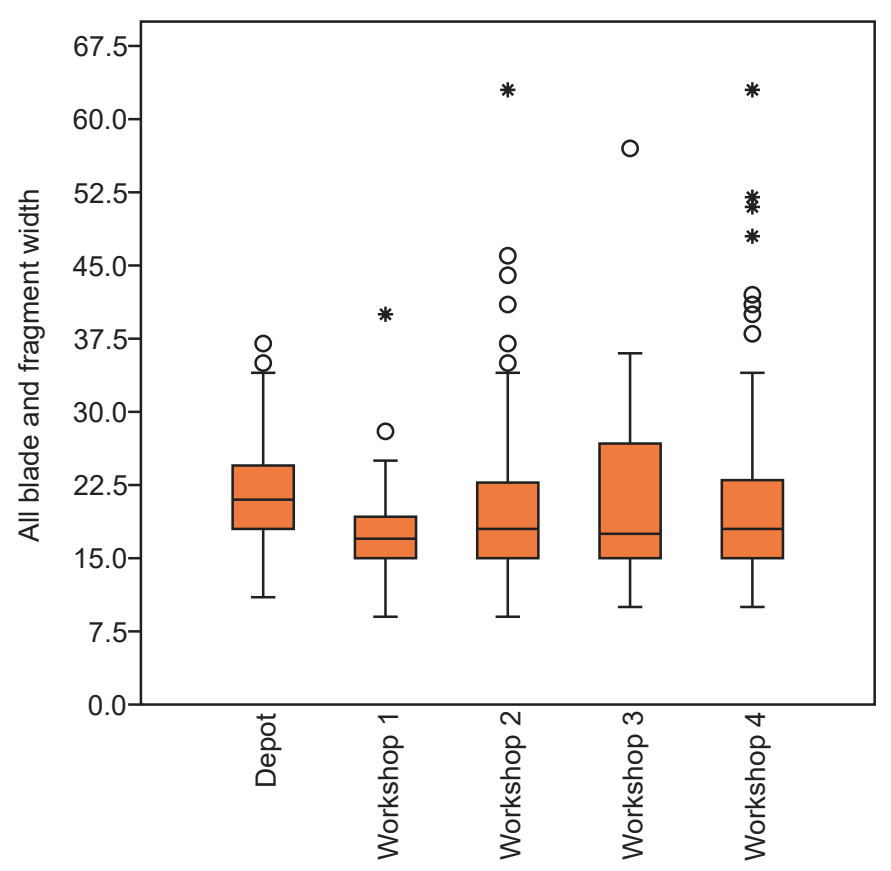

Figure 16. Boldogkőváralja-Tekeres-patak, width values of the complete and fragmentary blades of the five assemblages (the depot and Workshops 1-4).. Scale is in millimeters. Assembled by Norbert Faragó.

structure (van der Leeuw 1994). It is not surprising then when specific technological solutions are raised into a higher cognitive domain to serve as symbols. One example is the regular blade made by pressure technique, the know-how of which transferred a message during the spread of the European $\mathrm{Ne}$ olithic into the Scandinavian region (Knuttson 2001). Another example is the manufacturing of bifacial daggers in the same region during the dawn of the Bronze Age. According to their study, the most spectacular and most skilful phases of their manufacture were not hidden at all but were performed near the places of the utilization of these tools (Apel 2008).

In conclusion, it is possible to associate all our results with the works dedicated to this blade depot. Vértes correctly emphasized the standardized nature of the metric attributes of these blades, while he mistakenly considered them as markers of a specific industry, or a cultural entity (Vértes 1965). Later, Mester and Tixier successfully argued for the technical reasons behind this standardization, advocating for technological choices over typological or metrical reasons as true cultural markers (Mester \& Tixier 2013). Meanwhile, neither Vértes nor Mester and Tixier were concerned with the finds from the rest of the workshops; just Kaczanowska did (Kaczanowska 1985). However, she restricted her evaluation only to general and short statements, without a thorough evaluation and publication. Király, Faragó, and Mester later argued for the ritual aspect of assembling more than 500 very similar blades from the workshops into an accessible jar near a house, but the detailed comparison of the finds was still missing (Király et al. 2020). With our data and results presented here, we took one step forward to reconstruct a prehistoric act in its totality.

\section{Appendices - descriptive statistics}

\begin{tabular}{|c|c|c|c|c|c|c|c|c|c|c|}
\hline \multirow[b]{2}{*}{ Butt type } & \multicolumn{5}{|c|}{ Depot complete blade length } & \multicolumn{5}{|c|}{ Depot complete blade width } \\
\hline & atypic & dihedral & crushed & facetted & plain & atypic & dihedral & crushed & facetted & plain \\
\hline$N$ & 6 & 80 & 13 & 138 & 160 & 6 & 80 & 13 & 138 & 160 \\
\hline Min & 53 & 38 & 46 & 48 & 44 & 17 & 15 & 11 & 11 & 12 \\
\hline Max & 80 & 103 & 89 & 107 & 106 & 26 & 32 & 30 & 34 & 37 \\
\hline Sum & 381 & 5760 & 846 & 9606 & 11279 & 128 & 1818 & 260 & 2854 & 3437 \\
\hline Mean & 63.5 & 72 & 65.07692 & 69.6087 & 70.49375 & 21.33333 & 22.725 & 20 & 20.68116 & 21.48125 \\
\hline Std. error & 4.23281 & 1.44235 & 3.07484 & 0.98295 & 0.88279 & 1.42984 & 0.45631 & 1.41421 & 0.36625 & 0.36103 \\
\hline Variance & 107.50000 & 166.43040 & 122.91030 & 133.33480 & 124.69180 & 12.26667 & 16.65759 & 26.00000 & 18.51074 & 20.85499 \\
\hline Stand. dev & 10.36822 & 12.90079 & 11.08649 & 11.54707 & 11.16655 & 3.50238 & 4.08137 & 5.09902 & 4.30241 & 4.56673 \\
\hline Median & 63.5 & 70 & 65 & 69 & 70 & 20.5 & 23 & 20 & 20.5 & 21 \\
\hline 25 prentil & 53 & 64.25 & 58 & 61 & 64 & 18.5 & 20 & 16.5 & 18 & 18 \\
\hline 75 prentil & 71 & 80 & 69.5 & 77 & 77.75 & 25.25 & 25 & 24 & 24 & 24 \\
\hline Skewness & 0.61045 & 0.38577 & 0.54572 & 0.39787 & 0.19619 & 0.38018 & 0.02470 & 0.29417 & 0.22973 & 0.61428 \\
\hline Kurtosis & -0.24474 & 0.05724 & 0.99597 & -0.09034 & 0.23607 & -1.40979 & -0.62123 & 0.07203 & -0.25986 & 0.74983 \\
\hline Geom. mean & 62.81492 & 70.86329 & 64.22146 & 68.67191 & 69.60446 & 21.09733 & 22.35328 & 19.38583 & 20.23049 & 21.01127 \\
\hline Coeff. var & 16.32791 & 17.91776 & 17.03598 & 16.58854 & 15.84048 & 16.41741 & 17.95983 & 25.49510 & 20.80353 & 21.25913 \\
\hline
\end{tabular}

Appendix 1. Boldogkőváralja-Tekeres-patak. depot blade length and blade width descriptive statistics. 


\begin{tabular}{|c|c|c|c|c|c|c|c|c|c|c|}
\hline \multirow[b]{2}{*}{ Butt type } & \multicolumn{5}{|c|}{ Depot complete blade thickness } & \multicolumn{5}{|c|}{ Depot complete blade curvature } \\
\hline & atypic & dihedral & crushed & facetted & plain & atypic & dihedral & crushed & facetted & plain \\
\hline N & 6 & 80 & 13 & 138 & 160 & 6 & 80 & 13 & 138 & 160 \\
\hline Min & 4 & 3 & 3 & 2 & 2 & 2 & 0 & 2 & 0 & 0 \\
\hline Max & 8 & 11 & 8 & 11 & 12 & 7 & 13 & 7 & 12 & 11 \\
\hline Sum & 37 & 461 & 75 & 732 & 851 & 28 & 485 & 71 & 688 & 791 \\
\hline Mean & 6.166667 & 5.7625 & 5.769231 & 5.304348 & 5.31875 & 4.666667 & 6.0625 & 5.461538 & 4.985507 & 4.94375 \\
\hline Std. error & 0.74907 & 0.18508 & 0.42598 & 0.13784 & 0.11641 & 0.76012 & 0.25492 & 0.51410 & 0.18484 & 0.16992 \\
\hline Variance & 3.36667 & 2.74035 & 2.35897 & 2.62203 & 2.16820 & 3.46667 & 5.19858 & 3.43590 & 4.71512 & 4.61946 \\
\hline Stand. dev & 1.83485 & 1.65540 & 1.53590 & 1.61927 & 1.47248 & 1.86190 & 2.28004 & 1.85362 & 2.17143 & 2.14929 \\
\hline Median & 6.5 & 5.5 & 6 & 5 & 5 & 5 & 6 & 6 & 5 & 5 \\
\hline 25 prentil & 4 & 4.25 & 4.5 & 4 & 4 & 2.75 & 5 & 3.5 & 3 & 4 \\
\hline 75 prentil & 8 & 7 & 7 & 6 & 6 & 6.25 & 7 & 7 & 6 & 6 \\
\hline Skewness & -0.36154 & 0.90528 & -0.19687 & 0.93875 & 0.94190 & -0.39249 & 0.47973 & -0.80978 & 0.38781 & 0.42785 \\
\hline Kurtosis & -2.10274 & 0.88363 & -0.62615 & 1.69411 & 2.04846 & -0.94305 & 1.23262 & -0.94449 & 0.59394 & 0.40446 \\
\hline Geom. mean & 5.91913 & 5.54505 & 5.56216 & 5.07041 & 5.12720 & 4.29758 & 0.00000 & 5.08627 & 0.00000 & 0.00000 \\
\hline Coeff. var & 29.75429 & 28.72711 & 26.62219 & 30.52716 & 27.68472 & 39.89783 & 37.60888 & 33.93947 & 43.55489 & 43.47494 \\
\hline
\end{tabular}

Appendix 2. Boldogkőváralja-Tekeres-patak. depot blade thickness and blade curvature descriptive statistics.

\begin{tabular}{|c|c|c|c|c|c|c|c|c|c|c|}
\hline \multirow[b]{2}{*}{ Assemblage } & \multicolumn{5}{|c|}{ Whole assemblage complete blade length } & \multicolumn{5}{|c|}{ Whole assemblage complete blade width } \\
\hline & Depot & $\begin{array}{c}\text { Workshop } \\
1\end{array}$ & $\begin{array}{c}\text { Workshop } \\
2\end{array}$ & $\begin{array}{c}\text { Workshop } \\
3\end{array}$ & $\begin{array}{c}\text { Workshop } \\
4\end{array}$ & Depot & $\begin{array}{c}\text { Workshop } \\
1\end{array}$ & $\begin{array}{c}\text { Workshop } \\
2\end{array}$ & $\begin{array}{c}\text { Workshop } \\
3\end{array}$ & $\begin{array}{c}\text { Workshop } \\
4\end{array}$ \\
\hline N & 405 & 7 & 17 & 6 & 27 & 402 & 7 & 17 & 6 & 27 \\
\hline Min & 38 & 37 & 31 & 34 & 26 & 11 & 14 & 10 & 11 & 10 \\
\hline Max & 107 & 66 & 63 & 68 & 89 & 37 & 24 & 27 & 19 & 40 \\
\hline Sum & 28407 & 352 & 741 & 278 & 1200 & 8604 & 135 & 287 & 95 & 538 \\
\hline Mean & 70.14074 & 50.28571 & 43.58824 & 46.33333 & 44.44444 & 21.40299 & 19.28571 & 16.88235 & 15.83333 & 19.92593 \\
\hline Std. error & 0.58025 & 3.99830 & 2.33273 & 4.86256 & 2.79159 & 0.21874 & 1.62882 & 1.18471 & 1.22248 & 1.38873 \\
\hline Variance & 136.35890 & 111.90480 & 92.50735 & 141.86670 & 210.41030 & 19.23371 & 18.57143 & 23.86029 & 8.96667 & 52.07123 \\
\hline Stand. dev & 11.67728 & 10.57850 & 9.61807 & 11.91078 & 14.50553 & 4.38563 & 4.30946 & 4.88470 & 2.99444 & 7.21604 \\
\hline Median & 69 & 53 & 39 & 43.5 & 41 & 21 & 18 & 16 & 15.5 & 18 \\
\hline 25 prentil & 62 & 37 & 36.5 & 38.5 & 34 & 18 & 15 & 13 & 14 & 14 \\
\hline 75 prentil & 77 & 57 & 50.5 & 53.75 & 50 & 24.25 & 24 & 21 & 19 & 24 \\
\hline Skewness & 0.35311 & -0.08824 & 0.81670 & 1.38597 & 1.59715 & 0.28266 & 0.05926 & 0.31771 & -0.56486 & 0.97823 \\
\hline Kurtosis & 0.06704 & -0.71962 & -0.25837 & 2.33332 & 3.32169 & 0.00180 & -2.25259 & -0.52686 & 0.26078 & 0.95216 \\
\hline Geom. mean & 69.17674 & 49.29683 & 42.65863 & 45.19256 & 42.53651 & 20.94988 & 18.86806 & 16.21022 & 15.57879 & 18.77916 \\
\hline Coeff. var & 16.64835 & 21.03680 & 22.06576 & 25.70672 & 32.63743 & 20.49072 & 22.34534 & 28.93376 & 18.91225 & 36.21432 \\
\hline
\end{tabular}

Appendix 3. Boldogkőváralja-Tekeres-patak. whole assemblage blade length and blade width descriptive statistics. 


\begin{tabular}{|c|c|c|c|c|c|c|c|c|c|c|}
\hline \multirow[b]{2}{*}{ Assemblage } & \multicolumn{5}{|c|}{ Whole assemblage complete blade thickness } & \multicolumn{5}{|c|}{ Whole assemblage complete blade curvature } \\
\hline & Depot & $\begin{array}{c}\text { Workshop } \\
1\end{array}$ & $\begin{array}{c}\text { Workshop } \\
2\end{array}$ & $\begin{array}{c}\text { Workshop } \\
3\end{array}$ & $\begin{array}{c}\text { Workshop } \\
4\end{array}$ & Depot & $\begin{array}{c}\text { Workshop } \\
1\end{array}$ & $\begin{array}{c}\text { Workshop } \\
2\end{array}$ & $\begin{array}{c}\text { Workshop } \\
3\end{array}$ & $\begin{array}{c}\text { Workshop } \\
4\end{array}$ \\
\hline N & 7 & 17 & 6 & 27 & 405 & 7 & 17 & 6 & 27 & 87 \\
\hline Min & 4 & 4 & 5 & 3 & 0 & 0 & 0 & 0 & 0 & 10 \\
\hline Max & 14 & 11 & 9 & 27 & 13 & 5 & 5 & 6 & 8 & 63 \\
\hline Sum & 58 & 103 & 37 & 243 & 2109 & 8 & 32 & 12 & 45 & 1835 \\
\hline Mean & 8.28571 & 6.05882 & 6.16667 & 9.00000 & 5.20741 & 1.14286 & 1.88235 & 2.00000 & 1.66667 & 21.09195 \\
\hline Std. error & 1.24813 & 0.43276 & 0.65405 & 1.11197 & 0.10941 & 0.70470 & 0.26956 & 0.85635 & 0.36980 & 1.07692 \\
\hline Variance & 10.90476 & 3.18382 & 2.56667 & 33.38462 & 4.84797 & 3.47619 & 1.23529 & 4.40000 & 3.69231 & 100.89840 \\
\hline Stand. dev & 3.30224 & 1.78433 & 1.60208 & 5.77794 & 2.20181 & 1.86445 & 1.11144 & 2.09762 & 1.92154 & 10.04482 \\
\hline Median & 8 & 5 & 5.5 & 7 & 5 & 0 & 2 & 1.5 & 1 & 18 \\
\hline 25 prentil & 5 & 5 & 5 & 6 & 4 & 0 & 1.5 & 0.75 & 0 & 15 \\
\hline 75 prentil & 10 & 7 & 7.5 & 11 & 7 & 2 & 2 & 3 & 3 & 23 \\
\hline Skewness & 0.50383 & 1.39656 & 1.35376 & 1.91612 & 0.40169 & 1.87355 & 0.87724 & 1.75524 & 1.63931 & 1.97368 \\
\hline Kurtosis & 0.60060 & 2.37660 & 1.23967 & 3.77949 & 0.59782 & 3.43235 & 3.64534 & 3.65703 & 3.27438 & 4.34805 \\
\hline Geom. mean & 7.70544 & 5.84559 & 6.01266 & 7.72392 & 0.00000 & 0.00000 & 0.00000 & 0.00000 & 0.00000 & 19.36898 \\
\hline Coeff. var & 39.85457 & 29.45006 & 25.97971 & 64.19936 & 42.28226 & 163.13980 & 59.04514 & 104.88090 & 115.29230 & 47.62395 \\
\hline
\end{tabular}

Appendix 4. Boldogkőváralja-Tekeres-patak. whole assemblage blade thickness and blade curvature descriptive statistics.

\begin{tabular}{|c|c|c|c|c|c|c|c|c|c|c|}
\hline & \multicolumn{5}{|c|}{ Depot all blade and fragment width } & \multicolumn{5}{|c|}{ Whole assemblage blade and fragment width } \\
\hline & atypic & dihedral & crushed & facetted & plain & Depot & $\begin{array}{c}\text { Workshop } \\
1\end{array}$ & $\begin{array}{c}\text { Workshop } \\
2\end{array}$ & $\begin{array}{c}\text { Workshop } \\
3\end{array}$ & $\begin{array}{c}\text { Workshop } \\
4\end{array}$ \\
\hline $\mathrm{N}$ & 7 & 103 & 18 & 178 & 213 & 564 & 82 & 108 & 30 & 87 \\
\hline Min & 17 & 15 & 11 & 11 & 11 & 11 & 9 & 9 & 10 & 10 \\
\hline Max & 26 & 32 & 30 & 34 & 37 & 37 & 40 & 63 & 57 & 63 \\
\hline Sum & 151 & 2326 & 351 & 3663 & 4549 & 11979 & 1443 & 2129 & 622 & 1835 \\
\hline Mean & 21.57143 & 22.58252 & 19.5 & 20.57865 & 21.35681 & 21.23936 & 17.59756 & 19.71296 & 20.73333 & 21.09195 \\
\hline Std. error & 1.23167 & 0.42179 & 1.05796 & 0.32026 & 0.30797 & 0.18452 & 0.51149 & 0.78506 & 1.73995 & 1.07692 \\
\hline Variance & 10.61905 & 18.32401 & 20.14706 & 18.25649 & 20.20228 & 19.20193 & 21.45333 & 66.56170 & 90.82299 & 100.89840 \\
\hline Stand. dev & 3.25869 & 4.28066 & 4.48855 & 4.27276 & 4.49469 & 4.38200 & 4.63177 & 8.15854 & 9.53011 & 10.04482 \\
\hline Median & 21 & 23 & 19 & 21 & 21 & 21 & 17 & 18 & 17.5 & 18 \\
\hline 25 prentil & 19 & 19 & 16.75 & 17.75 & 18 & 18 & 15 & 15 & 15 & 15 \\
\hline 75 prentil & 25 & 26 & 21.5 & 23.25 & 24 & 24 & 19.25 & 22.75 & 26.75 & 23 \\
\hline Skewness & 0.09082 & -0.00518 & 0.56421 & 0.17777 & 0.53205 & 0.28108 & 1.54581 & 2.28811 & 2.10980 & 1.97368 \\
\hline Kurtosis & -1.20513 & -0.87198 & 0.78497 & -0.32454 & 0.64478 & -0.11428 & 5.64225 & 7.87460 & 6.19409 & 4.34805 \\
\hline Geom. mean & 21.35919 & 22.16857 & 19.01785 & 20.12836 & 20.89263 & 20.78375 & 17.06288 & 18.46851 & 19.15870 & 19.36898 \\
\hline Coeff. var & 15.10650 & 18.95561 & 23.01819 & 20.76308 & 21.04572 & 20.63151 & 26.32054 & 41.38665 & 45.96516 & 47.62395 \\
\hline
\end{tabular}

Appendix 5. Boldogkőváralja-Tekeres-patak. descriptive statistics of complete and fragmentary blade width values in the depot and in the whole assemblage.

\section{References}

Apel, J. (2008). Knowledge, Know-How and Raw Material - The Production of Late Neolithic Flint Daggers in Scandinavia. Journal of Archaeological Method and Theory, 15(1), 91-111. https://doi. org/10.1007/s10816-007-9044-2

Binford, L. R. \& Binford, S. R. (1966). A preliminary analysis of functional variability in the Mousterian of Levallois facies. American Anthropologist, 68(2), 238-295. https://doi.org/10.1525/ aa.1966.68.2.02a001030

Biró, K. T. (1987). Chipped stone industry of the Linearband Pottery culture in Hungary. In: Kozłowski, J. K., \& Kozłowski, S. K. (eds.), Chipped Stone Industries of the early Farming Cultures in Europe. Warsaw University Press, Kraków, 131-167.

Biró, K. T. (1998). Lithic Implements and the Circulation of Raw Materials in the Great Hungarian Plain during the Late Neolithic Period. Hungarian National Museum, Budapest.

Biró, K. T. (2009). Egy sváb menyecske hozománya. Gondolatok a szegvár-túzkövesi kőeszköz raktárlelet kapcsán. In: Bende L., \& Lőrinczy G. (szerk.), Medinától Etéig. Tisztelgő írások Csalog József születésének 100. évfordulóján. Móra Ferenc Múzeum, Szentes, 103-116. 
Clarke, D. L. (1968). Analytical archaeology. Methuen, London.

Dolukhanov, P. M., Kozlowski, J. K., \& Kozlowski, S. K. (1989). Multivariate analysis of upper palaeolithic and mesolithic stone assemblages. Typology and ecology. Prace archeologiczne 30. Nakladem Uniwersytetu Jagiellońskiego, Kraków.

Faragó, N. (2017). Differences in the selection of raw materials at the site of Polgár-Csőszhalom, northeast Hungary. Bulgarian e-Journal of Archaeology, 7, 85-115.

Faragó, N. (2020). Complex, household-based analysis of the stone tools of Polgár-Csőszhalom. Dissertationes Archaeologicae, 3(7), 301-329. https://doi.org/10.17204/dissarch.2019.301

Fogelin, L. (2007). The Archaeology of Religious Ritual. Annual Review of Anthropology, 36, 55-71. https://doi.org/10.1146/annurev. anthro.36.081406.094425

Füzesi, A., Faragó, N., \& Raczky, P. (2017). Tiszaug-Railway-station. An archaic Middle Neolithic community on the Great Hungarian Plain. Dissertationes Archaeologicae Ser. 3, 5, 7-66. https://doi. org/10.17204/dissarch.2017.7

Garrow, D. (2012). Odd deposits and average practice. A critical history of the concept of structured deposition. Archaeological Dialogues, 19, 85-115. https://doi.org/10.1017/\$1380203812000141

Gosden, C., \& Malafouris, L. (2015). Process archaeology (P-Arch). World Archaeology, 47, 701-717. https://doi.org/10.1080/00438243. 2015.1078741

Hammer, Ø., Harper, D.A.T., and Ryan, P. D. (2001). PAST: Paleontological Statistics Software Package for Education and Data Analysis. Palaeontologia Electronica, 4(1): 9.

Hodder, I. (1991). Interpretive Archaeology and Its Role. American Antiquity, 56, 7-18. https://doi.org/10.2307/280968

Hodson, F. R. (1969). Searching for structure within multivariate archaeological data. World Archaeology, 1(1), 90-105. https://doi.org/ 10.1080/00438243.1969.9979430

Kaczanowska, M. (1985). Rohstoffe, Technik und Typologie der neolithischen Feuersteinindustrien im Nordteil des Flussgebietes der Mitteldonau. Państwowe Wydawnictwo Nauokowe, Warszawa.

Kaczanowska, M., \& Kozłowski, J. K. (2016). The evolution of chipped stone industries in the "Polgár island" from the Middle Neolithic to the Early Copper Age. Folia Quaternaria, 84 67-84.

Kaczanowska, M., Kozłowski, J. K., \& Makkay J. (1981). Flint hoard from Endrőd, site 39 Hungary (Körös culture). Acta Archaeologica Carpathica, 21, 105-117.

Kaczanowska M., Kozłowski J. K., \& Sümegi, P. (2016). Chipped and ground stone implements from Polgár 31. Folia Quaternaria, 84, 5-66.

Kalicz, N., \& Makkay, J. (1977). Die Linienbandkeramik in der Grossen Ungarischen Tiefebene. Studia Archaeologica 7. Akadémiai Kiadó, Budapest.

Kemenczei, T. (1964). Boldogkőváralja. Archaeologiai Értesítő, 91, 253.

Király, A. (2018). Digital Data and Holocene Lithic Industries in the Sudanese Nile Valley: a Case Study. In: Kabaciński, J., Chłodnicki, M., Kobusiewicz, M., \& Winiarska-Kabacińska, M. (eds.), Desert and the Nile. Prehistory of the Nile Basin and the Sahara. Papers in honour of Fred Wendorf Studies in African Archaeology 15. Poznań Archaeological Museum, Poznań, 207-233.

Király, A., Faragó, N., \& Mester, Zs. (2020). Hasznos rítusok és haszontalan technikák. A rituális cselekvés régészeti azonosításának néhány elméleti kérdése egy pattintott kő leletegyüttes kap-

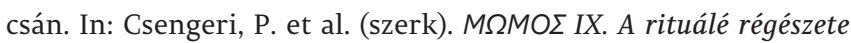
- Öskoros Kutatók IX. Összejövetelének konferenciakötete Miskolc, 2015. október 14-16. Dissertationes Archaeologicae Supplementum 7. ELTE BTK Régészettudományi Intézet, Budapest, 9-42. https:// doi.org/10.17204/dissarch.suppl3.9
Knutsson, H. (2001) Technology, mythology and the travels of the agriculture package in Europe. Documenta Praehistorica, 28, 117-132. https://doi.org/10.4312/dp.28.8

Leroi-Gourhan, A. (1964). Le geste et la parole tome I. Technique et langage. Albin Michel, Paris.

Leroi-Gourhan, A. (1965). Le geste et la parole tome II. La mémoire et les rythmes. Albin Michel, Paris.

Lemonnier, P. (1989). Bark capes, arrowheads and Concorde: on social representation of technology. In: Hodder, I. (ed.) The meanings of things. Material culture and Symbolic Expression. Routledge, London, 156-171.

Lengyel, Gy. (2018). Lithic analysis of the Middle and Late Upper Palaeolithic in Hungary. Folia Quaternaria, 86, 5-157. https://doi.org/ 10.4467/21995923FQ.18.001.9819

Mester, Zs., \& Faragó, N. (2016). Prehistoric exploitation of limnosilicites in Northern Hungary: Problems and perspectives. Archeologia Polona, 54, 33-50.

Mester, Zs., \& Tixier, J. (2013). „Pot à lames”: The Neolithic blade depot from Boldogkőváralja (Northeast Hungary). In: Anders, A., \& Kulcsár, G. (eds.), Moments in Time. Papers Presented to Pál Raczky on His 60th Birthday. Ösrégészeti Tanulmányok - Prehistoric Studies 1. Ősrégészeti Társaság - Eötvös Loránd University - L'Harmattan, Budapest, 173-185.

McNiven, I. J. (2013). Ritualized Middening Practices. Journal of Archaeological Method and Theory, 20, 552-587. https://doi.org/10.1007/ s10816-012-9130-y

Nagy, E. Gy., Kaczanowska, M., Kozłowski, J. K., Moskal-Del Hoyo, \& Lityńska-Zając, M. (2014). Evolution and environment of the eastern Linear Pottery culture: a case study in the site of PolgárPiócási-dúlő. Acta Archaeologica Academiae Scientiarum Hungaricae, 65, 217-284. https://doi.org/10.1556/AArch.65.2014.2.2

Pelegrin, J., Karlin, C., \& Bodu, P. (1988). « Chaînes opératoires » : un outil pour le préhistorien. In: Tixier, J. (dir.), Journée d'études technologiques en Préhistoire. Notes et Monographies Techniques 25. Editions du CNRS, Paris, 55-62.

Renfrew, C., \& Zubrow, E. (eds.) (1994). The Ancient Mind: Elements of Cognitive Archaeology, Cambridge University Press, Cambridge. https://doi.org/10.1017/CBO9780511598388

Richards, C. \& Thomas, J. (1984). Ritual activity and structured deposition in Later Neolithic Wessex. In: Bradley, R., \& Gardiner, J. (eds), Neolithic studies. A review of some current research. BAR Publishing, Oxford, 189-218.

Robb, J. E. (1998). The Archaeology of Symbols. Annual Review of Anthropology, 27, 329-346. https://doi.org/10.1146/annurev. anthro.27.1.329

Scerri, E.M.L., Gravina, B., Blinkhorn, J., \& Delagnes, A. (2016). Can Lithic Attribute Analyses Identify Discrete Reduction Trajectories? A Quantitative Study Using Refitted Lithic Sets. Journal of Archaeological Method and Theory, 23, 669-691. https://dx.doi. org/10.1007/s10816-015-9255-X

Schlanger, N. (1994). Mindful technology: unleashing the chaîne operatoire for an archaeology of mind. In: Renfrew, C., \& Zubrow, E.B.W. (eds.), The Ancient Mind: Elements of Cognitive Archaeology. Cambridge University Press, Cambridge, 143-151. https://doi. org/10.1017/CBO9780511598388.015

Siklósi, Zs. (2013). Traces of Social Inequality during the Late Neolithic in the Eastern Carpathian Basin. Dissertationes Pannonicae Ser. IV. Vol. 3. Eötvös Loránd University, Institute of Archaeological Sciences, Budapest.

Tálas, L. (ed.) (1987). The Late Neolithic of the Tisza region. Directorate of the Szolnok County Museums, Budapest-Szolnok. 
Texier, P-J., \& Meignen, L. (2012). Soixante années de technologie lithique : étapes marquantes, apports et écueils. In: Delpech, F., \& Jaubert, J. (eds.), François Bordes et la préhistoire. Documents préhistoriques 29. Éditions du CTHS, Paris, 133-139.

Tixier, J. (2012). A method for the study of stone tools / Méthodes pour l'étude des outillages lithiques. ArchéoLogiques 4. Musée National d'Histoire et d'Art, Luxembourg.

van der Leeuw, S. E. (1994). Cognitive aspects of 'technique'. In: Renfrew, C., \& Zubrow, E.B.W. (eds.), The Ancient Mind: Elements of Cognitive Archaeology. Cambridge University Press, Cambridge, 135-142. https://doi.org/10.1017/CBO9780511598388.014

Vértes, L. (1965). The depot of silex blades from Boldogkőváralja. A technological model of the manufacture of stone implements. Acta Archaeologica Academiae Scientiarium Hungaricae, 17, 129-136. 
